Article

\title{
The Chemical Composition of Brazilian Green Propolis and Its Protective Effects on Mouse Aortic Endothelial Cells against Inflammatory Injury
}

\author{
Xiaolan $\mathrm{Xu}^{1}$, Bo Yang ${ }^{2,3}$, Danfeng Wang ${ }^{4}$, Yuxuan Zhu ${ }^{2,3}$, Xiaoqing Miao ${ }^{3}$ \\ and Wenchao Yang ${ }^{1,3, * \mathbb{D}}$ \\ 1 College of Animal Science (College of Bee Science), Fujian Agriculture and Forestry University, \\ Fuzhou 350002, China; xlxufz@fafu.edu.cn \\ 2 College of Food Science, Fujian Agriculture and Forestry University, Fuzhou 350002, China; \\ 15225700066@163.com (B.Y.); z18350993003@126.com (Y.Z.) \\ 3 Bee Product Processing and Application Research Center of the Ministry of Education, \\ Fuzhou 350002, China; mxqsf88@126.com \\ 4 College of Plant Protection, Institute of Applied Ecology, Fujian Agriculture and Forestry University, \\ Fuzhou 350002, China; 91136459@163.com \\ * Correspondence: beesyang@gmail.com
}

Academic Editor: Soraia I. Falcão

Received: 5 September 2020; Accepted: 3 October 2020; Published: 10 October 2020

\begin{abstract}
Propolis has a very complex composition, with antibacterial, anti-inflammatory and other properties. To determine the composition of ethanol extracts of Brazilian green propolis (EEP-B) and their protective effect on mouse aortic endothelial cells (MAECs), the chemical composition of EEP-B was analysed by UPLC/Q-TOF-MS/MS, and the protective effect of EEP-B on the proliferation of lipopolysaccharide (LPS)-induced MAECs was determined by Cell Counting Kit-8 (CCK-8) assays. The protein levels of inflammatory cytokines tumour necrosis factor- $\alpha$ (TNF- $\alpha$ ) and interleukin- 6 (IL-6) were measured by enzyme-linked immunosorbent assay (ELISA), and ICAM-1, VCAM-1 and MCP-1 expressions were analysed by western blotting. The results showed that a total of 24 compounds belonging to cinnamic acids and flavonoids, including 3,5-diisopentenyl-4-hydroxycinnamic acid (artepillin C), kaempferide, 3-isoprenyl p-coumaric acid, pinocembrin and $4^{\prime}$-methoxy pinobanksin, were identified in EEP-B. Among them, a new component, suggested to be 5-isoprenyl caffeic acid p-coumaric acid ester, was reported for the first time. The LPS-induced levels of TNF- $\alpha$, IL-6, ICAM-1, VCAM-1 and MCP-1 were downregulated in response to 5, 10 and $20 \mu \mathrm{g} / \mathrm{mL}$ EEP-B. This study revealed that EEP-B could reduce LPS-induced inflammatory reactions, improve cell survival, and protect MAECs by regulating ICAM-1, VCAM-1 and MCP-1 expression. These findings could provide a theoretical basis for MAEC treatment using EEP-B.
\end{abstract}

Keywords: Brazilian green propolis; chemical composition; mouse aortic endothelial cells; anti-inflammatory

\section{Introduction}

Propolis contains very complex chemical components, mainly flavonoids and polyphenols, which vary depending on the geographical location, plant species and season [1-3]. The main plant sources of propolis are Populus spp. (Salicaceae) [4], Baccharis dracunculifolia [5], Dalbergia ecastaphyllum [6], Clusia (Clusiaceae) [7] and Azadirachta indica [8], resulting in the propolis composition being particularly complex. Among these, Baccharis dracunculifolia is the plant source of Brazilian green propolis, which contains isopentenylated phenylpropanoids and their derivatives, caffeoylquinic acids and some terpenes [9-11]. In contrast to poplar-type propolis, Brazilian propolis is mainly composed 
of phenolic acids and has an especially high level of artepillin C (3,5-diisopentenyl-4-hydroxycinnamic acid) $[12,13]$.

Propolis has been demonstrated to have many pharmacological properties, including antimicrobial, antioxidant, anti-tumour, anti-inflammatory and immunomodulatory activities [14-17]. In particular, propolis has an anti-inflammatory effect, which can prevent atherosclerosis, reduce blood lipids, affect angiogenesis, and play an important role in the prevention and treatment of cardiovascular diseases [18]. Previous studies have shown that propolis could inhibit inflammation by inhibiting inflammatory cytokines (TNF- $\alpha$, IL-1 $\beta$, and IL-6), the ERK1/MAPK pathway, NF- $k B$ activation, and neutrophil adhesion and transmigration (ICAM-1, VCAM-1 and E-selectin expression) [19]. Propolis extract could also effectively inhibit the levels of total cholesterol (TC), triglyceride (TG), non-high-density lipoprotein cholesterol (non-HDL-C), and the production of IL-6 and IL-17 in ApoE-/-mice fed a high-fat diet to protect vascular endothelial cells [20]. Some active ingredients in propolis, such as artepillin C [21,22], neovestitol-vestitol [23] and chrysin [24,25], have been proven to have strong physiological activity. As the most important component in green propolis, artepillin $C$ exerted robust antioxidant and anti-inflammatory activity to inhibit the levels of the cytokines TNF- $\alpha$, IL- $1 \beta$ and NF-KB in stimulated RAW264.7 macrophages [26].

The vascular endothelium is a single layer of cells lining the surface of the vascular lumen that can maintain the integrity of blood vessels and the normal structure and function of the blood vessel wall [27]. Endothelial damage can be caused by oxidative stress, inflammation, hypertension and other factors [28]. As a strong inflammatory promoter, lipopolysaccharide (LPS) can stimulate inflammation and the release of a large number of proinflammatory cytokines, such as TNF- $\alpha$, IL-1 $\beta$, IL- 6 and IL-10 $[29,30]$, which are involved in the formation of atherosclerotic lesions. Currently, protecting vascular endothelial cells and regulating the inflammatory response of vascular endothelial cells are important treatments for atherosclerosis.

Brazilian green propolis has a complex chemical composition and strong anti-inflammatory effects. In this study, to determine the composition of Brazilian green propolis and its protective effect on LPS-stimulated mouse aortic endothelial cells (MAECs), the components of Brazilian green propolis were analysed by UPLC-Q-TOF-MS, LPS was used to stimulate MAECS, and the levels of TNF- $\alpha$, IL-6, ICAM-1, VCAM-1 and MCP-1 were determined after propolis treatment to explore the protective effect of propolis on MAECS injured by LPS, as well as the possible mechanism.

\section{Results}

\subsection{Chemical Composition}

The levels of total polyphenols and flavonoids in EEP-B were $218.67 \mathrm{mg} / \mathrm{g}$ and $227.20 \mathrm{mg} / \mathrm{g}$, respectively. Chromatographic profiles and chemical compositions were determined by UPLC-Q-TOF-MS, and are shown in Figure 1 and Table 1. A total of 28 constituents was identified in EEP-B. These components mainly belong to cinnamic acids, of which artepillin $C$ was the most abundant component (relative content $35.68 \%$ ). In addition, there were four triterpenes detected, but their structures have not been identified. 
Table 1. Main components of the ethanol extracts of Brazilian propolis (EEP-B).

\begin{tabular}{|c|c|c|c|c|c|c|c|c|c|c|}
\hline No & $\begin{array}{l}\mathrm{tR} \\
(\mathrm{min})\end{array}$ & $\begin{array}{c}\lambda \max \\
(\mathrm{nm})\end{array}$ & $\begin{array}{l}\text { Selected } \\
\text { Ion }\end{array}$ & Formula & $\begin{array}{l}\text { Measured } \\
\text { Mass }\end{array}$ & $\begin{array}{l}\text { Calculated } \\
\text { Mass }\end{array}$ & $\begin{array}{l}\text { Mass } \\
\text { Error }\end{array}$ & MS/MS Fragmentation & Compound Name & $\begin{array}{c}\text { Relative } \\
\text { Area } \\
\text { (\%) }\end{array}$ \\
\hline 1 & 4.62 & 237,310 & {$[\mathrm{M}-\mathrm{H}]$} & $\mathrm{C}_{9} \mathrm{H}_{8} \mathrm{O}_{3}$ & 163.0400 & 163.0395 & 0.5 & $163.0400,119.0502,93.0368$ & $p$-Coumaric acid $\mathrm{a}, \mathrm{c}$ & $1.31 \%$ \\
\hline 2 & 6.18 & 324 & {$[\mathrm{M}-\mathrm{H}]$} & $\mathrm{C}_{25} \mathrm{H}_{24} \mathrm{O}_{12}$ & 515.1191 & 515.1190 & 0.1 & $353.0868,91.0554,179.0342,135.0444$ & Dicaffeoylquinic acid isomer $\mathrm{a}, \mathrm{d}$ & $0.48 \%$ \\
\hline 3 & 6.64 & 324 & {$[\mathrm{M}-\mathrm{H}]$} & $\mathrm{C}_{25} \mathrm{H}_{24} \mathrm{O}_{12}$ & 515.1193 & 515.1190 & 0.3 & $353.0871,191.0555,179.0343,135.0445$ & Dicaffeoylquinic acid a,d & $1.31 \%$ \\
\hline 4 & 9.06 & 253,372 & {$[\mathrm{M}-\mathrm{H}]$} & $\mathrm{C}_{15} \mathrm{H}_{10} \mathrm{O}_{7}$ & 301.0365 & 301.0348 & 1.7 & $243.02886,151.00304$ & Quercetin ${ }^{\mathrm{a}, \mathrm{c}}$ & $0.29 \%$ \\
\hline 5 & 10.96 & 292 & {$[\mathrm{M}-\mathrm{H}]$} & $\mathrm{C}_{15} \mathrm{H}_{12} \mathrm{O}_{5}$ & 271.0613 & 271.0606 & 0.7 & $271.0613,253.0504$ & Pinobanksin ${ }^{\mathrm{a}, \mathrm{c}}$ & $0.19 \%$ \\
\hline 6 & 11.26 & 292 & {$[\mathrm{M}-\mathrm{H}]$} & $\mathrm{C}_{16} \mathrm{H}_{14} \mathrm{O}_{6}$ & 301.0714 & 301.0712 & & $301.0714,283.0603,268.0367,152.0107$ & $4^{\prime}$-methoxy Pinobanksin a,e & $4.10 \%$ \\
\hline 7 & 11.40 & 265,365 & {$[\mathrm{M}-\mathrm{H}]$} & $\mathrm{C}_{15} \mathrm{H}_{10} \mathrm{O}_{6}$ & 285.0400 & 285.0399 & 0.1 & $285.0400,227.03402$ & Kaempferol a,b $^{a, b}$ & $0.30 \%$ \\
\hline 8 & 11.58 & 251,365 & {$[\mathrm{M}-\mathrm{H}]$} & $\mathrm{C}_{16} \mathrm{H}_{11} \mathrm{O}_{7}$ & 315.0505 & 315.0505 & 0 & $315.0505,300.0266,243.0292$ & Quercetin-methyl ether a & $0.43 \%$ \\
\hline 9 & 13.80 & 326 & {$[\mathrm{M}-\mathrm{H}]$} & $\mathrm{C}_{14} \mathrm{H}_{16} \mathrm{O}_{4}$ & 247.0971 & 247.0970 & 0.1 & $247.0971,203.10683$ & 5-isoprenyl caffeic acid a,f & $0.53 \%$ \\
\hline 10 & 15.52 & 315 & {$[\mathrm{M}-\mathrm{H}]$} & $\mathrm{C}_{14} \mathrm{H}_{16} \mathrm{O}_{3}$ & 231.1025 & 231.1021 & 0.4 & $187.1121,132.0575$ & 3-isoprenyl-p-Coumaric acid ${ }^{\mathrm{a}, \mathrm{e}}$ & $6.19 \%$ \\
\hline 11 & 17.11 & 313 & {$[\mathrm{M}-\mathrm{H}]$} & $\mathrm{C}_{19} \mathrm{H}_{24} \mathrm{O}_{4}$ & 315.1597 & 315.1596 & 0.1 & $315.1597,271.1692,253.1591,198.1043$ & 3-hydroxy-2,2-dimethy-8-prenylchromane-6-propenoic a,e & $3.39 \%$ \\
\hline 12 & 17.47 & 324 & {$[\mathrm{M}-\mathrm{H}]$} & $\mathrm{C}_{14} \mathrm{H}_{16} \mathrm{O}_{4}$ & 247.0971 & 247.0970 & 0.1 & $247.0971,179.0341,161.0236,135.0443$ & Caffeic acid isoprenyl ester $a, c$ & $0.46 \%$ \\
\hline 13 & 19.00 & 286 & {$[\mathrm{M}-\mathrm{H}]$} & $\mathrm{C}_{15} \mathrm{H}_{12} \mathrm{O}_{4}$ & 255.0662 & 255.0657 & 0.5 & 213.0552, $151.0031,107.0134$ & Pinocembrin ${ }^{a, c}$ & $5.56 \%$ \\
\hline 14 & 19.24 & 318 & {$[\mathrm{M}-\mathrm{H}]$} & $\mathrm{C}_{19} \mathrm{H}_{24} \mathrm{O}_{4}$ & 315.1597 & 315.1596 & 0.1 & $271.1675,253.1589,198.1041$ & $\begin{array}{l}\text { 3-hydroxy-2,2-dimethy-8-preylchromane-6-propenoic } \\
\text { isomer a,e }^{\text {a,e }}\end{array}$ & $0.45 \%$ \\
\hline 15 & 19.65 & 265,361 & {$[\mathrm{M}-\mathrm{H}]$} & $\mathrm{C}_{15} \mathrm{H}_{10} \mathrm{O}_{5}$ & 269.0456 & 269.0450 & 0.6 & $211.03914,145.0288,117.0340$ & Galangin a,b & $0.53 \%$ \\
\hline 16 & 20.35 & 265,365 & {$[\mathrm{M}-\mathrm{H}]$} & $\mathrm{C}_{16} \mathrm{H}_{11} \mathrm{O}_{6}$ & 299.0557 & 299.0556 & 0.1 & $284.0320,151.0029,107.0132$ & Kaempferide $a, c$ & $7.06 \%$ \\
\hline 17 & 20.68 & 292 & {$[\mathrm{M}-\mathrm{H}]$} & $\mathrm{C}_{17} \mathrm{H}_{14} \mathrm{O}_{6}$ & 313.0745 & 313.0712 & 3.3 & $253.0505,119.0498$ & Pinobanksinr-3-O-acetate ${ }^{\mathrm{a}, \mathrm{c}}$ & $0.37 \%$ \\
\hline 18 & 21.18 & 269,363 & {$[\mathrm{M}-\mathrm{H}]$} & $\mathrm{C}_{17} \mathrm{H}_{14} \mathrm{O}_{7}$ & 329.0665 & 329.0661 & 0.4 & $314.0424,299.0180,271.02431$ & Quercetin-dimethyl ether ${ }^{a, c}$ & $2.52 \%$ \\
\hline 19 & 24.25 & 319 & {$[\mathrm{M}-\mathrm{H}]$} & $\mathrm{C}_{23} \mathrm{H}_{22} \mathrm{O}_{6}$ & 393.1343 & 393.1338 & 0.5 & $349.1436,247.0967,163.0392,145.0289,117.0340$ & 5 -isoprenyl caffeic acid- $p$-coumaric acid ester a & $0.62 \%$ \\
\hline 20 & 25.84 & 318 & {$[\mathrm{M}-\mathrm{H}]$} & $\mathrm{C}_{19} \mathrm{H}_{24} \mathrm{O}_{4}$ & 315.1600 & 315.1596 & 0.5 & $245.1170,201.1279,146.0731$ & $\begin{array}{l}\text { 3-hydroxy-2,2-dimethy-8-preylchromane-6-propenoic } \\
\text { isomer a,e }\end{array}$ & $0.43 \%$ \\
\hline 21 & 27.17 & 287 & {$[\mathrm{M}-\mathrm{H}]$} & $\mathrm{C}_{19} \mathrm{H}_{24} \mathrm{O}_{3}$ & 299.1647 & 299.1647 & 0 & $255.1748,187.1117,161.0601$ & Diisoprenyl $-p$-Coumaric acid isomer ${ }^{\mathrm{a}, \mathrm{e}}$ & $4.49 \%$ \\
\hline 22 & 32.88 & 314 & {$[\mathrm{M}-\mathrm{H}]$} & $\mathrm{C}_{19} \mathrm{H}_{24} \mathrm{O}_{3}$ & 299.1652 & 299.1647 & 0.5 & $255.1750,201.1238,145.0652$ & Artepillin C (3,5-diisopentenyl-4-hydroxycinnamic acid) a,e & $35.68 \%$ \\
\hline 23 & 38.36 & 279 & {$[\mathrm{M}-\mathrm{H}]$} & $\mathrm{C}_{23} \mathrm{H}_{24} \mathrm{O}_{4}$ & 363.1588 & 363.1596 & -0.8 & $231.1021,187.1122,149.0621$ & 3-Prenyl-4-(dihydrocinnamoyloxy)-cinnamic acid a,d & $2.44 \%$ \\
\hline 24 & 38.51 & 308 & {$[\mathrm{M}-\mathrm{H}]$} & $\mathrm{C}_{28} \mathrm{H}_{32} \mathrm{O}_{5}$ & 447.2175 & 447.2171 & 0.4 & 297.1492, 253.1592, 198.1041, 149.0603, 105.0704 & $\begin{array}{l}\text { (E)-3-[2,3-dihydro-2-(1-methylethenyl)-7-prenyl- } \\
\text { 5-benzofuranyl]-2-propenoic acid }{ }^{\text {a,d }}\end{array}$ & $2.27 \%$ \\
\hline 25 & 40.73 & - & {$[\mathrm{M}-\mathrm{H}]$} & $\mathrm{C}_{30} \mathrm{H}_{48} \mathrm{O}_{4}$ & 471.3485 & 471.3474 & 1.1 & $517.3542,471.3485,407.3318$ & triterpenes & $0.94 \%$ \\
\hline 26 & 42.48 & - & {$[\mathrm{M}-\mathrm{H}]$} & $\mathrm{C}_{30} \mathrm{H}_{46} \mathrm{O}_{4}$ & 469.3323 & 469.3318 & 0.5 & $515.3377,469.3323,423.3260$ & triterpenes & $0.17 \%$ \\
\hline 27 & 43.25 & - & {$[\mathrm{M}-\mathrm{H}]$} & $\mathrm{C}_{30} \mathrm{H}_{48} \mathrm{O}_{4}$ & 471.3480 & 471.3474 & 0.6 & $517.3436,471.3481,339.1994$ & triterpenes & $0.24 \%$ \\
\hline 28 & 43.68 & & {$[\mathrm{M}-\mathrm{H}]$} & $\mathrm{C}_{30} \mathrm{H}_{46} \mathrm{O}_{4}$ & 469.3322 & 469.3318 & 0.4 & $515.3377,469.3322,407.3314$ & triterpenes & $2.26 \%$ \\
\hline
\end{tabular}

$\mathrm{tR}(\mathrm{min})$ : retention time (min); $\lambda$ max: the maximum absorption wavelength. ${ }^{\mathrm{a}}$ confirmed with MS fragmentation; ${ }^{\mathrm{b}}$ Confirmed with the standard; ${ }^{\mathrm{c}}$ confirmed with references [31];

${ }_{d}$ confirmed with references [32]; ${ }^{\mathrm{e}}$ confirmed with references [33]; ${ }^{\mathrm{f}}$ confirmed with references [34]. 


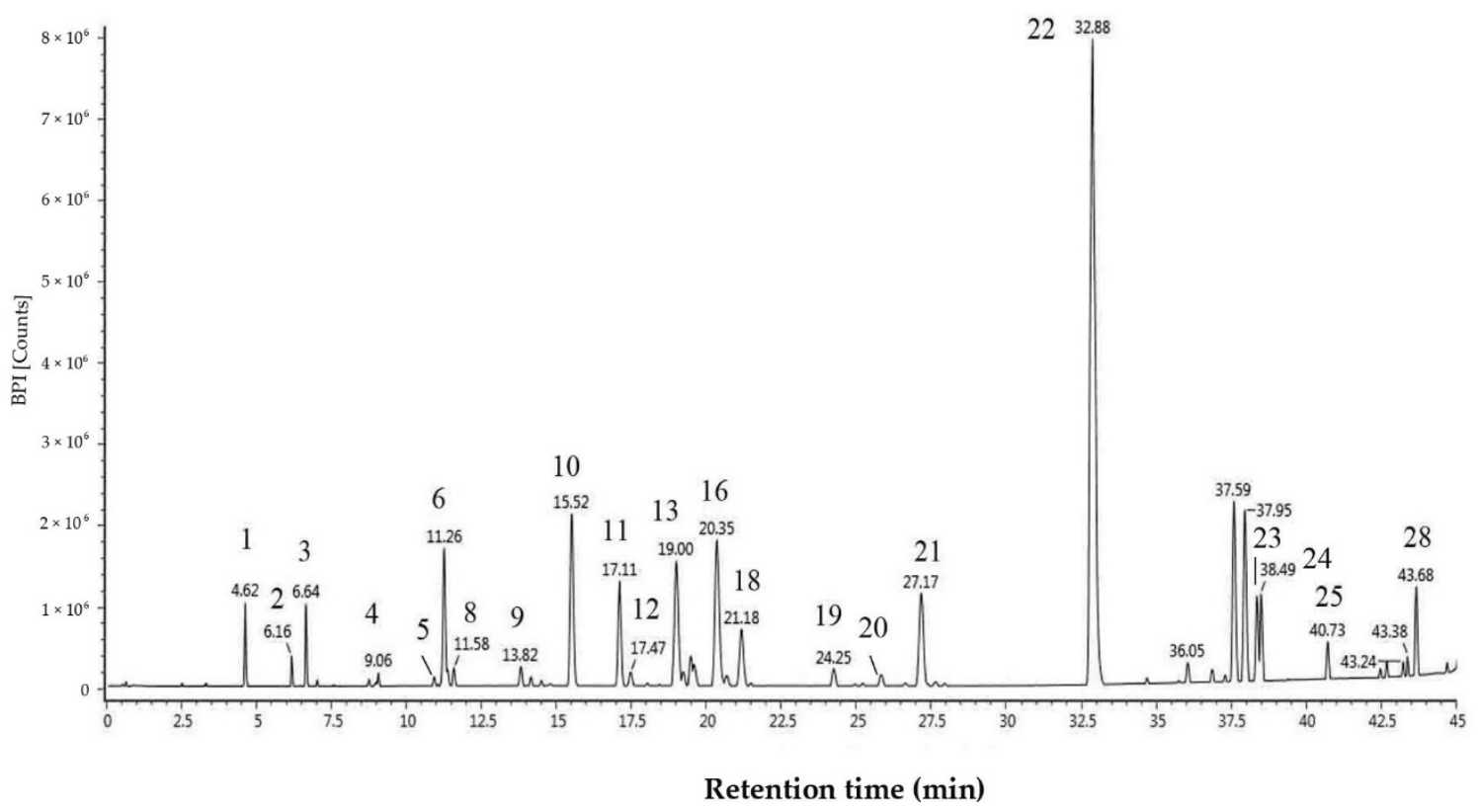

Figure 1. Chromatographic profile of 5-isoprenyl caffeic acid p-coumaric acid ester in Brazilian propolis.

In this study, a new compound ( $\mathrm{tR}=24.25 \mathrm{~min}$ ) with a molecular formula of $\mathrm{C}_{23} \mathrm{H}_{22} \mathrm{O}_{6}$ was tentatively identified. The molecular ion at $m / z 393.1343[\mathrm{M}-\mathrm{H}]^{-}$further fragmented to yield ions at $m / z 349.1436\left[\mathrm{M}-\mathrm{H}-\mathrm{CO}_{2}\right]^{-}$and $247.0967\left[\mathrm{M}-\mathrm{H}-\mathrm{C}_{9} \mathrm{H}_{6} \mathrm{O}_{2}\right]^{-}$. This compound also gave fragments at $\mathrm{m} / \mathrm{z}$ $162.8387\left[\mathrm{M}-\mathrm{H}-\mathrm{C}_{14} \mathrm{H}_{15} \mathrm{O}_{3}\right], 145.0289\left[\mathrm{M}-\mathrm{H}-\mathrm{C}_{14} \mathrm{H}_{15} \mathrm{O}_{3}-\mathrm{OH}\right]^{-}$and $117.0340\left[\mathrm{M}-\mathrm{H}-\mathrm{C}_{14} \mathrm{H}_{15} \mathrm{O}_{3}-\mathrm{OH}-\mathrm{CO}\right]^{-}$ by continuous fragmentation (Figure 2). As a result, its chemical structure was suggested as 5-isoprenyl caffeic acid p-coumaric acid ester (Figure 3).

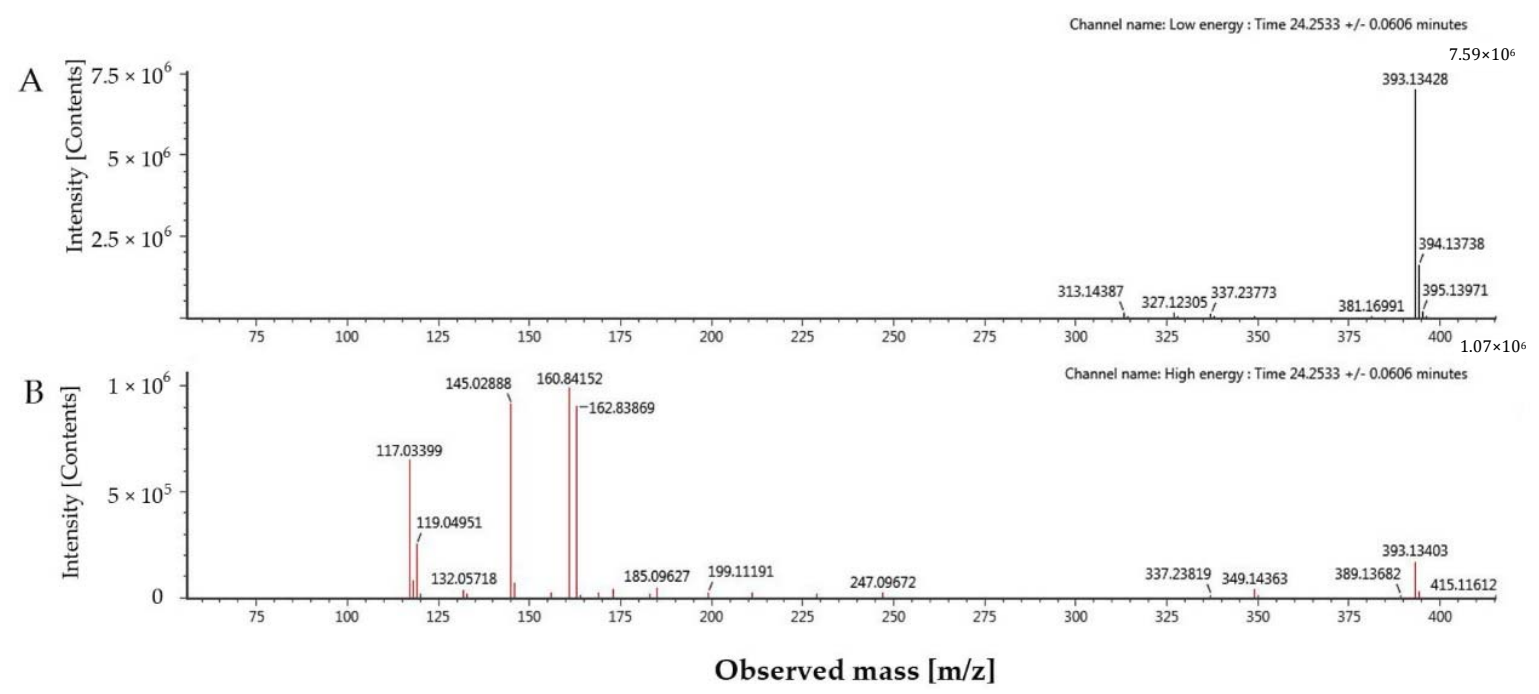

Figure 2. MS/MS spectra under low energy (A) and high energy (B) of 5-isoprenyl caffeic acid p-coumaric acid ester. 


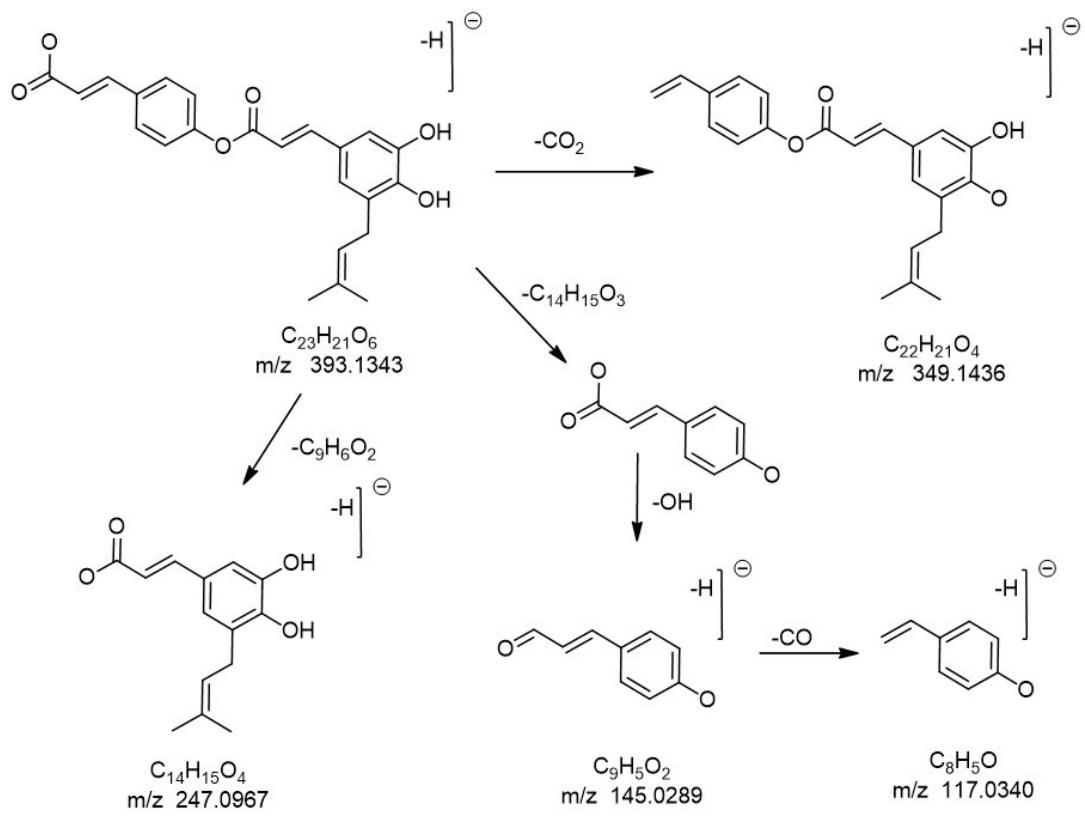

Figure 3. The fragmentation pathways of 5-isoprenyl caffeic acid p-coumaric acid ester.

\subsection{Effect of EEP-B on MACE Proliferation}

As shown in Figure 4, the survival rate of each group was measured by CCK-8 assays, and there were significant differences among all groups. The survival rate of the LPS-stimulated group was $67.35 \%$, which was significantly lower than that of the control group. The survival rates of the cells were significantly increased when the EEP-B was at the concentrations of 5, 10 and $20 \mu \mathrm{g} / \mathrm{mL}$, and the survival rate was the highest at $20 \mu \mathrm{g} / \mathrm{mL}$.

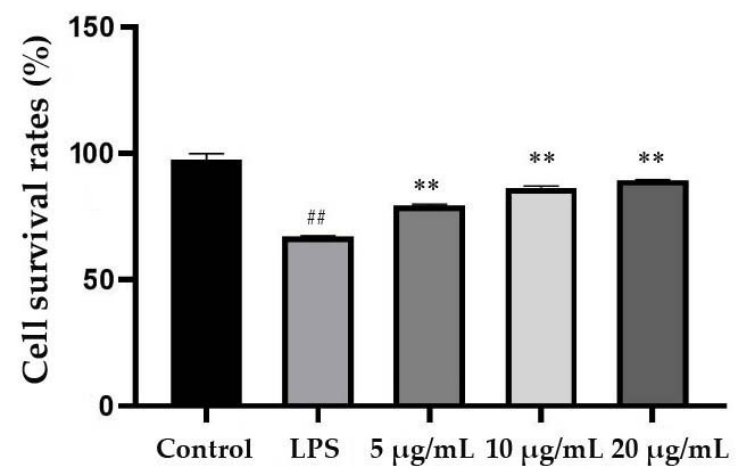

Figure 4. Influence of EEP-B on LPS-stimulated MACE growth. \#\# means extremely significant difference $(p<0.01)$ between LPS-stimulated group and control and ${ }^{* *}$ means extremely significant difference $(p<0.01)$ between propolis treatment group and LPS-stimulated group.

\subsection{Effect of EEP-B on the Levels of IL-6 and TNF- $\alpha$}

The expression levels of IL- 6 and TNF- $\alpha$ were measured by ELISA. As shown in Figure 5, compared with those of the control group, the amounts of IL- 6 and TNF- $\alpha$ secreted in the LPS-stimulated group were increased by 3.23- and 2.31-fold, respectively. After EEP-B treatment, the levels of IL-6 and TNF- $\alpha$ decreased significantly. At a concentration of $20 \mu \mathrm{g} / \mathrm{mL}$ EEP-B, the expression levels of these cytokines were the lowest. 


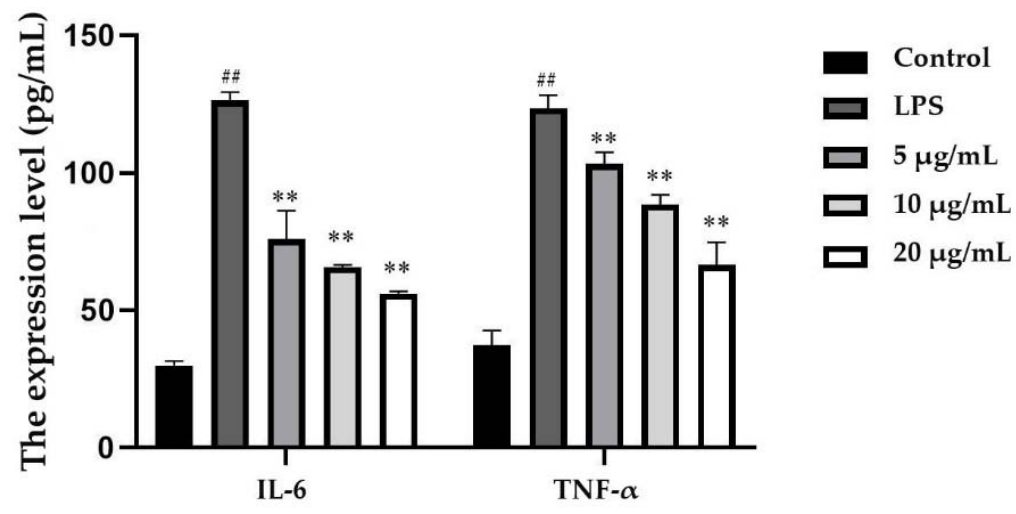

Figure 5. Effects of EEP-B on the levels of IL-6 and TNF- $\alpha$. \#\# means extremely significant difference $(p<0.01)$ between LPS-stimulated group and control and ${ }^{* *}$ means extremely significant difference $(p<0.01)$ between propolis treatment group and LPS-stimulated group.

\subsection{Effect of Propolis on the Levels of MCP-1, ICAM-1 and VCAM-1}

The levels of MCP-1, ICAM-1 and VCAM-1 were measured by western blotting (Figure 6). The results showed that the expression of MCP-1, ICAM-1 and VCAM-1 in the LPS group was significantly higher than that in the control group, and increased by 3.95-, 7.76- and 9.11-fold, respectively. In the EEP-B treatment group, the levels of MCP-1, ICAM-1 and VCAM-1 also decreased significantly, especially at a concentration of $20 \mu \mathrm{g} / \mathrm{mL}$.
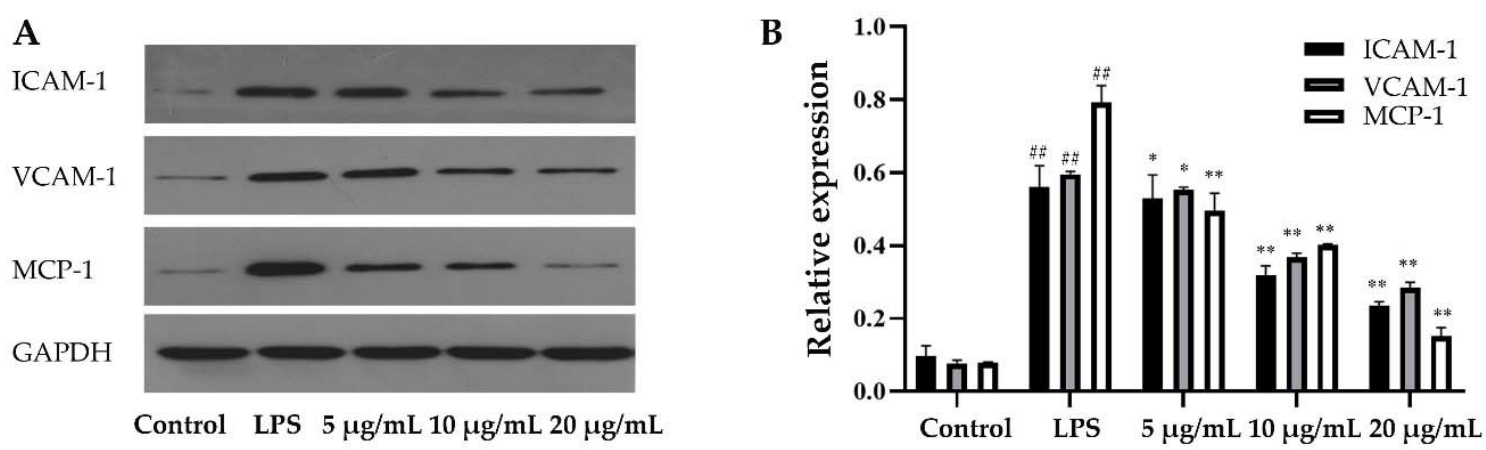

Figure 6. Effects of EEP-B on the levels of MCP-1, ICAM-1 and VCAM-1. (A). Protein expression of MCP-1, ICAM-1 and VCAM-1. (B). Relative expression of MCP-1, ICAM-1 and VCAM-1. \#\# means extremely significant difference $(p<0.01)$ between LPS-stimulated group and control, ${ }^{*}$ means significant difference $(p<0.05)$ and ${ }^{* *}$ means extremely significant difference $(p<0.01)$ between propolis treatment group and LPS-stimulated group.

\section{Discussion}

The chemical constituents of propolis vary in different plant sources. Brazilian propolis can be classified into 13 different types according to different geographical sources, resulting in the complexity of the components $[35,36]$. The main chemical constituents of Brazilian green propolis are coumaric acids. In the current study, prenylated derivatives of p-coumaric acid, diterpenes and flavonoids were detected. Among these components, the level of artepillin $C$ was much higher than that of the others, which is one of the characteristics of Brazilian propolis [37]. The level of artepillin C in propolis varies greatly depending on the geographical origin, and the samples collected from southeast Brazil are more abundant (usually 5-11\%) in this component than those from other regions [37]. In addition, the components with high levels were kaempferide (7.06\%), 3-isoprenyl p-coumaric acid $(6.19 \%)$, pinocembrin $(5.56 \%)$, diisoprenyl-p-coumaric acid isomer $(4.49 \%), 4^{\prime}$-methoxy pinobanksin $(4.10 \%)$ and 3-hydroxy-2,2-dimethyl-8-prenylchromane-6-propenoic (3.39\%), which was consistent with previous studies [12]. 
Compared with poplar-type propolis, which we analysed previously, only six components, quercetin, pinobanksin, kaempferol, pinocembrin, galangin and pinobanksin-3-O-acetate, which are flavonoids, were the same [38]. Among them, the levels of pinobanksin, galangin and pinobanksin-3-O-acetate in poplar-type propolis were greater than $5 \%, 9 \%$ and $9 \%$, respectively, while those in Brazil green propolis were all less than $0.5 \%$, indicating great differences between these two types of propolis. The chemical composition of propolis from different regions is very complex, and new compounds have been discovered in recent years. Righi et al. identified schaftoside (apigenin-8-C-glucosyl-6-C-arabinose) in green propolis and prenylated flavonoids in Brazilian propolis [39]. Tazawa et al. identified clerodane diterpene rel-(5S,6S,8R,9R,10S,18R,19S)-18,19-epoxy-2-oxocleroda-3,12(E),14-triene-6,18,19-triol 18,19-diacetate 6-benzoate in brown propolis from Brazil [40]. In this study, the new component 5-isoprenyl caffeic acid p-coumaric acid ester was reported for the first time.

Lipopolysaccharide (LPS) is involved in the development of atherosclerosis, especially in the initial process of inflammation in atherosclerotic vessels. LPS can activate and damage endothelial cells and cause changes in the morphology and function of vascular endothelial cells $[29,30]$. In atherosclerotic plaque formation, vascular endothelial cell apoptosis accelerates the process of atherosclerosis [41]. In this study, LPS was used to stimulate MAECs, resulting in increased IL- 6 and TNF- $\alpha$ expression. TNF- $\alpha$ and IL- 6 are important inflammatory cytokines whose secretion can be stimulated by hyperglycaemia, hyperlipidaemia and other metabolic abnormalities [42,43]. IL-6 can promote the expression of adhesion molecules and other inflammatory mediators in vascular endothelial cells, and enhance the local inflammatory response, and it is an important inflammatory factor involved in tissue lesions [44]. IL-6 expression was correlated with intimal thickening and decreased elasticity [45]. Tumour necrosis factor (TNF- $\alpha$ ) can inhibit endothelial cell proliferation, activate the nuclear factor- $\mathrm{KB}$ (NF- $\mathrm{kB}$ ) signalling pathway, induce the expression of intercellular adhesion molecules such as ICAM-1 and VCAM-1, and promote monocyte infiltration to participate in the inflammatory pathological process of atherosclerosis (AS) [46-48].

EEP-B inhibited the expression of IL- 6 and TNF- $\alpha$ in MAECs, which was in accordance with a previous report, suggesting that Brazilian green propolis extract has good anti-inflammatory effects by inhibiting the proinflammatory cytokines IL-6 and TNF- $\alpha$ [17]. Both Chinese propolis and Brazilian propolis have good immunomodulatory effects on LPS-induced inflammation. Chinese propolis modulates the suppression of autophagy and the MAPK/NF- $\mathrm{kB}$ signalling pathway to protect vascular endothelial cells from LPS stimulation [49]. Brazilian green propolis exerts strong anti-inflammatory effects by inhibiting the production of many cytokines, such as IL- $1 \alpha$, IL-1 $\beta$, IL- 4 , IL-6, TNF- $\alpha$ and MCP-1, in stimulated J774A cells [39]. Similar to green propolis, red propolis extract can also inhibit the release of inflammatory cytokines, including TNF- $\alpha$, IL-1 $\beta$, CXCL1/KC and CXCL2/MIP-2. In addition, Brazilian propolis can prevent neutrophil migration into the peritoneal cavity, and reduce leukocyte rolling and adhesion on the mesenteric microcirculation [50].

Propolis plays an important role in the prevention and treatment of cardiovascular diseases [20,51,52]. In initial atherosclerotic lesions, propolis polyphenol extracts improved the lipid profile and decreased the atherosclerotic lesion area [53], as well as reducing the total cholesterol (TC), low density lipoprotein-cholesterol (LDL-C), triglycerides and thiobarbituric acid-reactive substance concentrations [54]. The propolis component chrysin has been confirmed to inhibit plasma plasminogen activator inhibitor 1 (PAI-1) production, and could be used to treat or prevent thrombotic disorders [25]. The expressions of ICAM-1, VCAM-1 and MCP-1 were rapidly upregulated upon stimulation with the inflammatory factor LPS. The high expression of ICAM-1 enhances the adhesion of monocytes to endothelial cells, VCAM-1 can promote monocyte adhesion to endothelial cells, and monocyte chemotactic protein-1 (MCP-1) can activate monocytes by binding with receptors [55,56]. The current study revealed that Brazilian green propolis could reduce the expression levels of ICAM-1, VCAM-1 and MCP-1, in order to inhibit the migration of monocytes from the blood circulation to the intima of the blood vessels, reduce the aggregation of foam cells and lipids in the arterial wall, and inhibit the 
chemotaxis of monocytes to the lesion site, thereby reducing the accumulation of lipids in the intima and damage to the intima of blood vessels.

\section{Materials and Methods}

\subsection{Preparation of Experimental Samples}

Brazilian green propolis was supplied by Fujian Shenfeng Technology Development Co., Ltd. (Fuzhou, China). Propolis was extracted using ethanol $(70 \%, v / v)$ according to a previously described method [38]. The ultrasonic wave method was used to extract propolis, and beeswax was removed. The ethanol extracts of Brazilian propolis were named EEP-B.

\subsection{Chemical Analysis of EEP-B}

The quantification of total polyphenol and phenolic contents and chemical composition analysis were also performed according to a previously described method [28]. The quantification of total polyphenols was performed using the Folin-Ciocalteu method, and gallic acid was used as a standard. The total flavonoid content was determined as described in the national standards for propolis in China (GB/T 24283-2018), and rutin was used as a standard. UPLC-ESI-MS analysis was performed on a Waters UPLC system, and the mobile phases consisted of $0.1 \%$ formic acid in water (A) and acetonitrile (B). The mass spectra were obtained using a Waters definition accurate-mass quadrupole time-of-flight (Q-TOF) Xevo G2-XS mass spectrometer (Waters Ltd., Elstree, Hertfordshire, UK), which was equipped with an ESI source, in both positive and negative ion modes.

\subsection{Cell Culture}

MAECs and reagents for cell culture were purchased from Procell Life Science and Technology Co. (Wuhan, China). Cells were cultured to a density of $1 \times 10^{5} / \mathrm{mL}$ at $37^{\circ} \mathrm{C}$ in $5 \% \mathrm{CO}_{2}$ and then divided into the following five groups: cells not treated with LPS or propolis that were used as control, cells stimulated with LPS $(10 \mu \mathrm{g} / \mathrm{mL})$, and cells stimulated with LPS $(10 \mu \mathrm{g} / \mathrm{mL})$ that were treated with different concentrations of EEP-B $(5,10$ and $20 \mu \mathrm{g} / \mathrm{mL})$.

\subsection{Cell Viability Assay}

Cells were added to each well at a density of $1 \times 10^{5} / \mathrm{mL}$ and cultured for $24 \mathrm{~h}$, then $10 \mu \mathrm{L}$ of Cell Counting Kit-8 (CCK-8) solution (Beyotime Biotechnology, Shanghai, China) was added and further cultured for $4 \mathrm{~h}$ at $37^{\circ} \mathrm{C}$ in $5 \% \mathrm{CO}_{2}$. Then, the absorbance was measured at $450 \mathrm{~nm}$. The cell viability $(\%)$ was calculated by the following formula: (absorbance of experimental wells/absorbance of control wells) $\times 100 \%$.

\subsection{ELISA Analysis of IL-6 and TNF- $\alpha$ Expression}

The cells were cultured for $24 \mathrm{~h}$ and used for enzyme-linked immunosorbent assay (ELISA) analysis. The supernatant of each group was analysed according to the procedures of the ELISA kit (Neobioscience, Shenzhen, China). The absorbance of each sample was measured at $450 \mathrm{~nm}$ by a microplate reader (Diatek, Wuxi, China), and the concentrations of IL- 6 and TNF- $\alpha$ were calculated.

\subsection{Western Blot Analysis of ICAM-l, VCAM-1 and MCP-1 Expression}

The cells were cultured for $24 \mathrm{~h}$ and used for western blot analysis. Radio immunoprecipitation assay (RIPA) buffer was used to lyse the cells, and the protein concentration was measured by the bicinchoninic acid (BCA) method using the Pierce ${ }^{\mathrm{TM}}$ Rapid Gold BCA Protein Assay Kit (Elabscience, Wuhan, China). Total protein samples from each group were extracted for sodium dodecyl sulphate polyacrylamide gel electrophoresis (SDS-PAGE). The proteins were transferred to a polyvinylidene fluoride (PVDF) membrane, incubated with the primary antibody against the target protein overnight at $4{ }^{\circ} \mathrm{C}$ and washed 5 times using Tris-buffered saline Tween-20 (TBST). Then, the secondary antibody 
was added and incubated for $1 \mathrm{~h}$ at room temperature, and the membrane was washed with TBST again. Finally, Clarity Western ECL Substrate was used for luminescence detection, and AlphaEaseFC was used to analyse the gel image. Glyceraldehyde-3-phosphate dehydrogenase (GAPDH) was used as a loading control.

\subsection{Statistical Analysis}

All experiments were performed in triplicate. The data are expressed as the mean \pm standard deviation $(n=3)$. Statistical analysis was performed using t-tests and one-way ANOVA with SPSS software. Differences of $p<0.05$ were considered statistically significant.

\section{Conclusions}

Propolis possesses rich chemical components and robust anti-inflammatory activity. In this study, the chemical composition of Brazilian green propolis was analysed by UPLC-Q-TOF-MS. A total of 28 compounds was identified, and a new component, 5-isoprenyl caffeic acid p-coumaric acid ester, was tentatively identified for the first time. In addition, EEP-B showed strong anti-inflammatory effects by inhibiting the levels of the cytokines TNF- $\alpha$ and IL-6, and protecting MAECs by regulating ICAM-1, VCAM-1 and MCP-1 expression. This study provides new insights into the chemical components and the anti-inflammatory activities of Brazilian green propolis.

Author Contributions: Conceptualization, X.X. and W.Y.; Data curation, B.Y. and Y.Z.; Formal analysis, D.W.; Funding acquisition, X.M. All authors have read and agreed to the published version of the manuscript.

Funding: This research was supported by Modern Agro-industry Technology Research System (CARS-44-KXJ20).

Conflicts of Interest: The authors declare no conflict of interest. The founding sponsors had no role in the design of the study; in the collection, analyses, or interpretation of data; in the writing of the manuscript, and in the decision to publish the results.

\section{References}

1. Wioleta, P.; Renata, N.; Urszula, G.D.; Lemieszek, M.K.; Rzeski, W. LC-ESI-MS/MS Identification of Biologically Active Phenolic Compounds in Mistletoe Berry Extracts from Different Host Trees. Molecules 2017, $22,624$. [CrossRef]

2. Oruç, H.H.; Sorucu, A.; Ünal, H.H.; Aydin, L. Effects of season and altitude on biological active certain phenolic compounds levels and partial standardization of propolis. Ank. Üniv. Vet. Fak. Derg. 2017, 64, 13-20.

3. Valencia, D.; Alday, E.; Robles-Zepeda, R.; Garibay-Escobar, A.; Galvez-Ruiz, J.C.; Salas-Reyes, M.; Jiménez-Estrada, M.; Velazquez-Contreras, E.; Hernandez, J.; Velazquez, C. Seasonal effect on chemical composition and biological activities of Sonoran propolis. Food Chem. 2012, 131, 645-651. [CrossRef]

4. Ristivojević, P.; Trifković, J.; Andrić, F.; Milojković-Opsenicab, D. Poplar-type Propolis: Chemical Composition, Botanical Origin and Biological Activity. Nat. Prod. Commun. 2015, 10, 1869-1876. [CrossRef]

5. Lemos, M.; Barros, M.P.D.; Sousa, J.P.B.; Barros, M.P.D.; Sousa, J.P.B.; Filho, A.A.D.S.; Bastos, J.K.; Andrade, S.F.D. Baccharis dracunculifolia, the main botanical source of Brazilian green propolis, displays antiulcer activity. J. Pharm. Pharmacol. 2010, 59, 603-608. [CrossRef]

6. Regueira-Neto, M.D.S.; Tintino, S.R.; Rolón, M.; Coronal, C.; Vega, M.C.; Balbino, V.D.Q.; Coutinho, H.D.D.M. Antitrypanosomal, antileishmanial and cytotoxic activities of Brazilian red propolis and plant resin of Dalbergia ecastophyllum (L) Taub. Food Chem. Toxicol. 2018, 2018, S0278691518302370.

7. Cunha, M.G.D.; Rosalen, P.L.; Franchin, M.; de Alencar, S.M.; Ikegaki, M.; Ransom, T.; Beutler, J.A. Antiproliferative Constituents of Geopropolis from the Bee Melipona scutellaris. Planta Med. 2015, 82, 190-194. [CrossRef]

8. Popova, M.; Dimitrova, R.; Al-Lawati, H.T.; Tsvetkova, I.; Najdenski, H.; Bankova, V. Omani propolis: Chemical profiling, antibacterial activity and new propolis plant sources. Chem. Cent. J. 2013, 7, 158. [CrossRef] 
9. Park, Y.K.; Paredes-Guzman, J.F.; Aguiar, C.L.; Alencar, S.M.; Fujiwara, F.Y. Chemical constituents in Baccharis dracunculifolia as the main botanical origin of southeastern Brazilian propolis. J. Agric. Food Chem. 2004, 52, 1100-1103. [CrossRef]

10. Chang, R.; Piló-Veloso, D.; Morais, S.A.L.; Nascimento, E.A. Analysis of a Brazilian green propolis from Baccharis dracunculifolia by HPLC-APCI-MS and GC-MS. Rev. Bras. De Farmacogn. 2008, 18, 549-556. [CrossRef]

11. Rodrigues, D.M.; De Souza, M.C.D.; Arruda, C.; Pereira, R.A.S. The Role of Baccharis dracunculifolia and its Chemical Profile on Green Propolis Production by Apis mellifera. J. Chem. Ecol. 2019, 46, 150-162. [CrossRef] [PubMed]

12. Matsuda, A.H.; Almeida-Muradian, L.B.D. Validated method for the quantification of artepillin-C in Brazilian propolis. Phytochem. Anal. 2008, 19, 179-183. [CrossRef] [PubMed]

13. Barth, O.M.; Freitas, A.D.S.D.; Matsuda, A.H.; Almeida-Muradian, L.B.D. Botanical origin and Artepillin-C content of Brazilian propolis samples. Grana Palynol. 2013, 52, 129-135. [CrossRef]

14. Cunha, M.G.D.; Franchin, M.; de Carvalho Galvão, L.C.; de Ruiz, A.L.; de Carvalho, J.E.; Ikegaki, M.; de Alencar, S.M.; Koo, H.; Rosalen, P.L. Antimicrobial and antiproliferative activities of stingless bee Melipona scutellaris geopropolis. BMC Complement. Altern. Med. 2013, 13, 23. [CrossRef] [PubMed]

15. Hatano, A.; Nonaka, T.; Yoshino, M.; Ahn, M.R.; Tazawa, S.; Araki, Y.; Kumazawa, S. Antioxidant Activity and Phenolic Constituents of Red Propolis from Shandong. China. Food Sci. Technol. Res. 2012, 18, 577-584. [CrossRef]

16. Funakoshi-Tago, M.; Okamoto, K.; Izumi, R.; Tago, K.; Yanagisawa, K.; Narukawa, Y.; Kiuchi, F.; Kasahara, T.; Tamura, H. Anti-inflammatory activity of flavonoids in Nepalese propolis is attributed to inhibition of the IL-33 signaling pathway. Int. Immunopharmacol. 2015, 25, 189-198. [CrossRef]

17. Machado, J.L.; Assunçao, A.K.; da Silva, M.C.; Reis, A.S.; Costa, G.C.; Arruda, D.D.; Rocha, B.A.; Vaz, M.M.; Paes, A.M.; Guerra, R.N.; et al. Brazilian Green Propolis: Anti-Inflammatory Property by an Immunomodulatory Activity. Evid. Based Complement. Altern. Med. 2012, 2012, 157652. [CrossRef]

18. Lima, L.D.C.; Andrade, S.P.; Campos, P.P.; Barcelos, L.S.; Soriani, F.M.; Moura, S.A.L.; Ferreira, M.A.N.D. Brazilian green propolis modulates inflammation, angiogenesis and fibrogenesis in intraperitoneal implant in mice. BMC Complement. Altern. Med. 2014, 14, 177. [CrossRef]

19. Franchin, M.; Freires, I.A.; Lazarini, J.G.; Dias, N.B.; Cunha, M.G.D.; Colón, D.F.; Alencar, S.M.D.; Rosalen, P.L. The use of Brazilian propolis for discovery and development of novel anti-inflammatory drugs. Eur. J Med. Chem. 2018, 153, 49-55. [CrossRef]

20. Fang, Y.; Sang, H.; Yuan, N.; Sun, H.; Yao, S.; Wang, J.; Qin, S. Ethanolic extract of propolis inhibits atherosclerosis in Apo E-knockout mice. Lipids Health Dis. 2013, 12, 123. [CrossRef]

21. Messerli, S.M.; Ahn, M.R.; Kunimasa, K.; Yanagihara, M.; Tatefuji, T.; Hashimoto, K.; Mautner, V.; Uto, Y.; Hori, H.; Kumazawa, S.; et al. Artepillin C (ARC) in Brazilian green propolis selectively blocks oncogenic PAK1 signaling and suppresses the growth of NF tumors in mice. Phytother. Res. 2010, 23, 423-427. [CrossRef]

22. Veiga, R.S.; Mendonça, S.D.; Mendes, P.B.; Paulino, N.; Mimica, M.J.; Netto, A.A.L.; Lira, I.S.; López, B.G.C.; Negrão, V.; Marcucci, M.C. Artepillin C and phenolic compounds responsible for antimicrobial and antioxidant activity of green propolis and Baccharis dracunculifolia DC. J. Appl. Microbiol. 2017, 122, 911-920. [CrossRef] [PubMed]

23. Bueno-Silva, B.; Alencar, S.M.; Koo, H.; Ikegaki, M.; Silva, G.V.J.; Napimoga, M.H.; Rosalen, P.L. Anti-Inflammatory and Antimicrobial Evaluation of Neovestitol and Vestitol Isolated from Brazilian Red Propolis. J. Agric. Food Chem. 2013, 61, 4546-4550. [CrossRef] [PubMed]

24. RMarkiewicz-Żukowska, R.; Car, H.; Naliwajko, S.K.; Sawicka, D.; Szynaka, B.; Chyczewski, L.; Isidorov, V.; Borawska, M.H. Ethanolic extract of propolis, chrysin, CAPE inhibit human astroglia cells. Adv. Med. Sci. 2012, 57, 208-216.

25. Ohkura, N.; Takata, Y.; Ando, K.; Kanai, S.; Watanabe, E.; Nohira, T.; Atsumi, G. Propolis and its constituent chrysin inhibit plasminogen activator inhibitor 1 production induced by tumour necrosis factor- $\alpha$ and lipopolysaccharide. J. Apic. Res. 2015, 51, 179-184. [CrossRef]

26. Szliszka, E.; Mertas, A.; Czuba, Z.P.; Król, W. Inhibition of Inflammatory Response by Artepillin C in Activated RAW264.7 Macrophages. Evid. Based Complement. Altern. Med. 2013, 2013, 735176. [CrossRef]

27. Tennant, M.; Mcgeachie, J.K. Blood vessel structure and function: A brief update on recent advances. Aust. N. Z. J. Surg. 1990, 60, 747-753. [CrossRef] [PubMed] 
28. Watson, T.; Goon, P.K.Y.; Lip, G.Y.H. Endothelial progenitor cells, endothelial dysfunction, inflammation, and oxidative stress in hypertension. Antioxid. Redox Signal 2008, 10, 1079-1088. [CrossRef]

29. Woo, M.S.; Park, J.S.; Choi, I.Y.; Kim, W.K. Inhibition of MMP-3 or -9 suppresses lipopolysaccharide-induced expression of proinflammatory cytokines and iNOS in microglia. J. Neurochem. 2008, 106, 770-780. [CrossRef]

30. Lu, W.Q.; Qiu, Y.; Li, T.J.; Xia, T.; Sun, L.N.; Chen, W.S. Timosaponin B-II inhibits pro-inflammatory cytokine induction by lipopolysaccharide in BV2 cells. Arch. Pharmacal Res. 2009, 32, 1301-1308. [CrossRef]

31. Falcao, S.I.; Vale, N.; Gomes, P.; Domingues, M.R.; Freire, C.; Cardoso, S.M.; Vilas-Boas, M. Phenolic Profiling of Portuguese Propolis by LC-MS Spectrometry: Uncommon Propolis Rich in Flavonoid Glycosides. Phytochem. Anal. 2013, 24, 309-318. [CrossRef] [PubMed]

32. Gardana, C.; Scaglianti, M.; Pietta, P.; Simonetti, P. Analysis of the polyphenolic fraction of propolis from different sources by liquid chromatography-tandem mass spectrometry. J. Pharm. Biomed. Anal. 2007, 45, 390-399. [CrossRef] [PubMed]

33. Midorikawa, K.; Banskota, A.H.; Tezuka, Y.; Nagaoka, T.; Matsushige, K.; Message, D.; Huertas, A.A.G.; Kadota, S. Liquid chromatography-mass spectrometry analysis of propolis. Phytochem. Anal. 2001, 12, 366-373. [CrossRef]

34. Hayashi, K.; Komura, S.; Isaji, N.; Ohishi, N.; Yagi, K. Isolation of antioxidative compounds from Brazilian propolis: 3,4-dihydroxy-5-prenylcinnamic acid, a novel potent antioxidant. Chem. Pharm. Bull. 1999, 47, 1521-1524. [CrossRef]

35. Park, Y.K.; Alencar, S.M.; Aguiar, C.L. Botanical origin and chemical composition of Brazilian propolis. J. Agric. Food Chem. 2002, 50, 2502-2506. [CrossRef] [PubMed]

36. Silva, B.B.; Rosalen, P.L.; Cury, J.A.; Ikegaki, M.; Souza, V.C.; Esteves, A.; Alencar, S.M. Chemical composition and botanical origin of red propolis, a new type of Brazilian propolis. Evid. Based Complement. Altern. Med. 2008, 5, 313-316. [CrossRef]

37. Zhang, C.P.; Shen, X.G.; Chen, J.W.; Jiang, X.S.; Wang, K.; Hu, F.L. Artepillin C, is it a good marker for quality control of Brazilian green propolis? Nat. Prod. Res. 2017, 31, 2441-2444. [CrossRef]

38. Xu, X.; Pu, R.; Li, Y.; Wu, Z.; Li, C.; Miao, X.; Yang, W. Chemical Compositions of Propolis from China and the United States and their Antimicrobial Activities Against Penicillium notatum. Molecules 2019, 24, 3576. [CrossRef]

39. Szliszka, E.; Kucharska, A.Z.; Sokół-Łętowska, A.; Mertas, A.; Czuba, Z.P.; Król, W. Chemical Composition and Anti-Inflammatory Effect of Ethanolic Extract of Brazilian Green Propolis on Activated J774A.1 Macrophages. Evid. Based Complement. Altern. Med. 2013, 2013, 976415. [CrossRef]

40. Righi, A.A.; Negri, G.; Salatino, A. Comparative chemistry of propolis from eight Brazilian localities. Evid. Based Complement. Altern. Med. 2013, 2013, 267878. [CrossRef]

41. Spagnoli, L.G.; Bonanno, E.; Sangiorgi, G.; Mauriello, A. Role of Inflammation in Atherosclerosis. J. Nucl. Med. 2007, 48, 1800-1815. [CrossRef] [PubMed]

42. Saxena, M.; Srivastava, N.; Banerjee, M. Association of IL-6, TNF- $\alpha$ and IL-10 gene polymorphisms with type 2 diabetes mellitus. Mol. Biol. Rep. 2013, 40, 6271-6279. [CrossRef] [PubMed]

43. Ebaid, H.; Bashandy, S.A.E.; Alhazza, I.M.; Hassan, I.; Al-Tamimi, J. Efficacy of a Methanolic Extract of Adansonia digitata Leaf in Alleviating Hyperglycemia, Hyperlipidemia, and Oxidative Stress of Diabetic Rats. Biomed Res. Int. 2019, 2019, 2835152. [CrossRef] [PubMed]

44. Nerstedt, A.; Johansson, A.; Andersson, C.X.; Cansby, E.; Smith, U.; Mahlapuu, M. AMP-activated protein kinase inhibits IL-6-stimulated inflammatory response in human liver cells by suppressing phosphorylation of signal transducer and activator of transcription 3 (STAT3). Diabetologia 2010, 53, 2406-2416. [CrossRef]

45. Nishida, M.; Moriyama, T.; Ishii, K.; Takashima, S.; Yoshizaki, K.; Sugita, Y.; Yamauchi-Takihara, K. Effects of IL-6, adiponectin, CRP and metabolic syndrome on subclinical atherosclerosis. Clin. Chim. Acta 2007, 384, 99-104. [CrossRef]

46. Jiang, Y.; Jiang, L.L.I.; Maimaitirexiati, X.M.Z.Y.; Zhang, Y.; Wu, L. Irbesartan attenuates TNF- $\alpha$-induced ICAM-1, VCAM-1, and E-selectin expression through suppression of NF-kB pathway in HUVECs. Eur. Rev. Med. Pharm. Sci. 2015, 19, 3295-3302.

47. Wu, S.; Xu, H.; Peng, J.; Wang, C.; Jin, Y.; Liu, K.; Sun, H.; Qin, J. Potent anti-inflammatory effect of dioscin mediated by suppression of TNF- $\alpha$-induced VCAM-1, ICAM-1and EL expression via the NF- $\mathrm{kB}$ pathway. Biochimie 2015, 110, 62-72. [CrossRef] 
48. Chang, C.C.; Chu, C.F.; Wang, C.N.; Wu, H.T.; Bi, K.W.; Pang, J.H.S.; Huang, S.T. The anti-atherosclerotic effect of tanshinone IIA is associated with the inhibition of TNF- $\alpha$-induced VCAM-1, ICAM-1 and CX3CL1 expression. Phytomed. Int. J. Phytother. Phytopharm. 2014, 21, 207-216. [CrossRef]

49. Xuan, H.; Yuan, W.; Chang, H.; Liu, M.; Hu, F. Anti-inflammatory effects of Chinese propolis in lipopolysaccharide-stimulated human umbilical vein endothelial cells by suppressing autophagy and MAPK/NF-KB signaling pathway. Inflammopharmacology 2018, 27, 561-571. [CrossRef]

50. Bueno-Silva, B.; Franchin, M.; Alves, C.D.F.; Denny, C.; Colón, D.F.; Cunha, T.M.; Alencar, S.M.; Napimoga, M.H.; Rosalen, P.L. Main pathways of action of brazilian red propolis on the modulation of neutrophils migration in the inflammatory process. Phytomedicine 2016, 23, 1583-1590. [CrossRef]

51. Öğretmen, F.; Inanan, B.E.; Öztürk, M. Protective effects of propolis on cryopreservation of common carp (Cyprinus carpio) sperm. Cryobiology 2014, 68, 107-112. [CrossRef] [PubMed]

52. Bueno-Silva, B.; Rosalen, P.L.; Alencar, S.M.; Maye, M.P.A. Anti-inflammatory mechanisms of neovestitol from Brazilian red propolis in LPS-activated macrophages. J. Funct. Foods 2017, 36, 440-447. [CrossRef]

53. Daleprane, J.B.; Freitas, V.D.S.; Pacheco, A.; Rudnicki, M.; Faine, L.A.; Dörr, F.A.; Ikegaki, M.; Salazar, L.A.; Ong, T.P.; Abdalla, D.S.P. Anti-atherogenic and anti-angiogenic activities of polyphenols from propolis. J. Nutr. Biochem. 2012, 23, 557-566. [CrossRef] [PubMed]

54. Nader, M.A.; El-Agamy, D.S.; Suddek, G.M. Protective effects of propolis and thymoquinone on development of atherosclerosis in cholesterol-fed rabbits. Arch. Pharmacal Res. 2010, 33, 637-643. [CrossRef] [PubMed]

55. Hofmann, N.; Lachnit, N.; Streppel, M.; Witter, B.; Neiss, W.F.; Guntinas-Lichius, O.; Angelov, D.N. Increased expression of ICAM-1, VCAM-1, MCP-1, and MIP- $1 \alpha$ by spinal perivascular macrophages during experimental allergic encephalomyelitis in rats. BMC Immunol. 2002, 3, 11. [CrossRef]

56. Fan, J.; Li, X.; Zhong, L.; Tong, H.; Di, J.; Liu, F.; Zhao, H.H.; Bai, S.L. MCP-1, ICAM-1 and VCAM-1 are present in early aneurysmal dilatation in experimental rats. Folia Histochem. Et Cytobiol. 2010, 48, 455-461. [CrossRef]

Sample Availability: Samples of the compounds are not available from the authors.

(C) 2020 by the authors. Licensee MDPI, Basel, Switzerland. This article is an open access article distributed under the terms and conditions of the Creative Commons Attribution (CC BY) license (http://creativecommons.org/licenses/by/4.0/). 